\title{
Robustness of a Distributed Knowledge Management Model
}

\author{
Pedersen, Mogens Kuhn; Holm Larsen, Michael
}

Document Version

Final published version

Publication date:

2003

\section{License \\ CC BY-NC-ND}

Citation for published version (APA):

Pedersen, M. K., \& Holm Larsen, M. (2003). Robustness of a Distributed Knowledge Management Model. Department of Informatics INF, Copenhagen Business School. Working Paper / Institut for Informatik. Handelshøjskolen i København No. 13

Link to publication in CBS Research Portal

\section{General rights}

Copyright and moral rights for the publications made accessible in the public portal are retained by the authors and/or other copyright owners and it is a condition of accessing publications that users recognise and abide by the legal requirements associated with these rights.

\section{Take down policy}

If you believe that this document breaches copyright please contact us (research.lib@cbs.dk) providing details, and we will remove access to the work immediately and investigate your claim. 


\section{Robustness of a Distributed Knowledge Management Model}

\author{
Mogens Kühn Pedersen \\ Department of Informatics, \\ Copenhagen Business School \\ Tel.: +45-3815-2405 \\ E-mail:mk.inf@cbs.dk
}

\author{
Michael Holm Larsen \\ Department of Informatics, \\ Copenhagen Business School \\ Tel.: +45-3815-2385 \\ E-mail:mhl.inf@cbs.dk
}

\begin{abstract}
In globalizing competitive markets knowledge exchange between business organizations requires incentive mechanisms to ensure tactical purposes while strategic purposes are subject to joint organization and other forms of contractual obligations. Where property of knowledge (e.g. patents and copyrights) and contractbased knowledge exchange do not obtain network effectiveness because of prohibitive transaction costs in reducing uncertainty, we suggest a robust model for peer produced knowledge within a distributed setting. The peer produced knowledge exchange model relies upon a double loop knowledge conversion with symmetric incentives in a network since the production of actor specific knowledge makes any knowledge appropriation by use of property rights by the actors irrelevant. Without property rights in knowledge the actor network generates opportunity for incentive symmetry over a period of time. The model merges specific knowledge with knowledge from other actors into a decision support system specific for each actor in the network in recognition of actor role differences. The article suggests a set of 9 static and 5 dynamic propositions for the model to maintain symmetric incentives between different actor networks. The model is proposed for business networks.
\end{abstract}

\section{Introduction}

The centralized knowledge creation model promotes the idea of making knowledge available to the whole organization as the purpose of knowledge management (Nonaka 1994, Nonaka et al. 1994, Nonaka \& Takeuchi 1995, El Sawy \& Bowles 1997, Favela 1997, Davenport \& Klahr 1998). Knowledge management (KM) faces the challenge of how to ensure dynamic updating of codified as well as un-codified knowledge. The decision-making qualities of relevant and timely information for decision support come to the fore in the concept of information specificity, which stipulates the value of knowledge without complete property rights necessarily stipulated (Choudhury and Sampler 1997). The alternative to a centralized knowledge management model is a distributed knowledge management (DKM) model. The DKM model generates knowledge amongst decision-makers in interdependent businesses on a continuous basis. Moreover, the DKM model redistributes the outcome for a time efficient knowledge use amongst participants in networks of peer produced knowledge. We regard interdependent decision makers as actors, which either may be individuals or organizations. We find distributed knowledge management networks with peer production where the individuals with the best information available from other actors can perform tasks relevant to themselves in the network (Benkler 2002-3, p.7).

Peer production is a third mode of allocation alongside markets and hierarchies (Coase 1937, Williamson 1975). Peer production provides an information gain over firms and markets, but only if the network develops mechanisms that avoid creating property rights to the knowledge and which ensures continuous relevance and value of the specific knowledge to their organization.

"Peer production has an advantage over firms and markets because it allows larger groups of individuals to scour larger groups of resources in search of materials, projects, collaborations, and combinations than do firms or individuals who function in markets. This is because when production is organized on a market or firm model, transaction costs associated with property and contract limit the access of people to each other, to resources and to projects, but do not do so when it is organized on a peer production model" (Benkler 2002).

A mechanism to sustain the "peer production" we find in a distributed knowledge management model if symmetric incentives for contributing quality knowledge is provided for by the set-up.

Incentives are considered as any form of benefit which is of value to the respective actor. The benefits may be tangible or intangible, e.g. monetary payments or specific information. 
Symmetric incentives are regarded as "equally divided" benefits between the involved parties or actors. By "equally divided" benefits we understand that the benefits to the individual actor are perceived relevant and valuable. The benefits is not necessary of the same nature or content, but the "perceived amount" of benefits in the form of knowledge, information, data, products or services, etc., are considered comparable. Hence, the individual actors will have the impression that they give some and they gain some, and that the exchange provides them with "equal" benefits.

Asymmetric incentives are incentives that are not "equally" divided, meaning that one actor may conduct certain activities and provide an other actor with relevant and specific information, but does not receive an "equal" amount of benefits.

If asymmetry prevails, peer production turns into benefits for one actor rather than for all disrupting participatory and contributive justice. This happens if property right in peer-produced knowledge is invoked. Asymmetry would also apply if any single actor could "defect" contributing to the peer production and yet reap benefits. Trust in the distributed knowledge network would fade (Adler 2001).

Generally, if the cost of organizing knowledge acquisition on peer basis is lower than the cost of using the market, and the cost of peering is lower than the cost of hierarchical organization, then peer production will emerge (Benkler 2002).

We may note that knowledge exchange facilitated by information and communication technologies (ICT) across space and time are much cheaper and more efficient than ever before, which permits the coordination of distributed knowledge and exploitation of its specificity for production and distribution of services and products.

Symmetry in opportunities to exploit knowledge and time specificity ensures continuous knowledge creation in a network. Knowledge creation in this article means knowledge specificity irrespective of whether knowledge is tacit or explicit (Choudhury \& Sampler 1997).

The centralized KM model consists in a single loop conversion, i.e. from individual, knowledge specificity into organizational, collective knowledge made available to all individuals where each individual ad hoc converts the global knowledge into decision support. The distributed KM model, see e.g. figure 2, requires a double loop conversion by adding to the centralized model the conversion of organizational, collective knowledge into knowledge specificity taking responsibility for making knowledge creation available for decision support. The latter process also makes for the difference between a centralized KM system that is passive in regard to decision making and an active decision support system that is distributed.

The relevance of the distributed model complements the incentive problems of knowledge sharing in the supply chain literature. Applications of the model can be found in supply network decision support systems with symmetric incentives for information sharing and knowledge creation.

The research objective of this paper is to add to the existing knowledge base of distributed knowledge management by establishing a set of propositions with regard to static and dynamic aspects of robustness of a distributed knowledge management model.

Hence, the research questions becomes: What are necessary conditions for establishing and maintaining robustness of a distributed knowledge management model.

The research method relies mainly on literature studies and reflections steaming from the authors training in social science, economics and engineering. The analysis of the distributed knowledge management model relies upon an actor network perspective as this is responsive towards relations within and between business networks.

In the following section the DKM model is positioned in the literature of knowledge management in order to verify the relevance of this research contribution. Consecutively, the DKM model is presented as a basis for the discussion of robustness.

\section{The Evolution of Knowledge Management}

The first knowledge management models focused on knowledge acquisition issues much along the lines of AI research a decade before (Constant et al. 1994). Incentive schemes moved to the fore as knowledge management became a high-priority management objective in major consultancies. The management challenge in knowledge intensive businesses became how to make team members in knowledge creation also contribute in sharing business methodologies efficiently to provide for the needs of clients. This issue was captured in the classic article of Nonaka from 1994 on organizational knowledge creation. In recent years, competition has increasingly ruled out this knowledge management strategy and at the same time brought to the attention of management the opportunities for a focused use of information technologies for knowledge acquisition and dissemination within the organization (Ciborra \& Andreu 1996, Borghoff 1997, Davenport \& Prusak 1998). 
The following models moved on to offer a knowledge repository much inspired by enterprise resource planning models and the concept of centralized, corporate databases. In these models we find information quality issues along with best practice objectives that take knowledge across functional entities, between divisions or subsidiaries to make knowledge an organizational asset (Davenport \& Klahr 1998). Disseminating knowledge was a matter of information retrieval and acquisition by each user as (s)he saw fit. Little or no decision support was offered from these repositories. What they offered were results of previous learning that only could be accessed if known to exist. "Much of the knowledge management movement in business schools and punditry since the mid-1990s was concerned with mitigating the looseness of managerial hierarchy as an information processing mechanism. Mitigating this lossiness is the primary job of CIOs." (Benkler 2002-3, p.42).

A third kind of models moved on to widen the scope of knowledge management by including business partners in a broader network of knowledge exchange. In particular manufacturing and service suppliers in customer support knowledge took advantage of the Internet in moving knowledge beyond organizational boundaries (E1 Sawy \& Bowles 1997, Hagel \& Rayport 1997). The supply chain attracted attention with its scope for increase of overall efficiency. The linear model of a knowledge flow of the demands of customers to dealers and distributors did not transform into value-added knowledge before considering the advantage from using the World Wide Web using rich information representations.

The model of supply chain management relates a significant share of all trade to opportunities of knowledge management for efficiency purposes thus representing a significant part of all business models. The supply chain network has been shown to benefit from information technology in the order fulfillment process (Strader et al. 1998). Unlike previous often hypothetical discussions of virtual organizations, the supply chain network decision support system provides a robust knowledge based structure where the knowledge exchange enhances the performance efficiency of all participating in the network.

The model we will present differs in a significant aspect from other models catering only for knowledge sharing discarding the specific nature of network business relations but stressing the decision support capability (Sridhar 1998). We argue that exchange of peer produced knowledge in a network will generate performance advantages to the participants not achieved by contractual knowledge exchange. Further, we suggest that advantages may prevail if peer produced knowledge sustain symmetry of incentives, which means that the actors are equally positioned to apply that for production of knowledge specificity.

\section{Actor Network Distributed Knowledge Management}

The following table rephrases the insights from the literature review above into tasks of the process owner, classified by the nature of the issues that the process owner needs to tackle

The raison d'être of network distributed knowledge management resides in actor network role differentiation (Callon 1991, Hull et al 1999). Originating in innovation studies the actor network concept now permeates into the economics and sociology of organizing entities ('intermediaries') and actors that are defined through their relationships. The nature of flows of knowledge (the 'intermediaries') between actors in computer-based networks takes on a dimension of symmetric incentives not otherwise found. In traditional economic analysis interdependencies across several market boundaries go unaccounted, an exception is Porter's clusters (1990, 1998a, 1998b), and in sociology these are abstracted into institutional categories in neglect of actors. Actor network theory allows for both autonomy and interdependence of actors in networks constructed by that which is exchanged, the intermediary, here specific knowledge taking account of each actor's specific role in the network.

In a business value chain the division of labor allocates different tasks for each actor. These tasks require specific and global knowledge in varying combinations for their completion. The resource-based view of the firm argues that for each actor compared to others in the same market the one succeeding the best in the value chain holds somewhat unique resources. The resource differential also explains the positioning in the value chain by reference to rents and quasi-rents from these resources (Wernerfelt 1984, Milgrom and Roberts 1992, Foss 1997). The information associated with the resource-based view exhibits the characteristics of asset specificity from the point of view of transaction cost economics (Williamson $1985,1986,1994)$. In this section this specificity is examined in more detail.

\subsection{Information Specificity}


Information specificity is defined as "the extent to which the value of information is restricted to its use and/or acquisition by specific individuals or during specific time periods" (Choudhury and Sampler 1997:29). Information specificity with regard to environmental scanning reflects a drive for timely and relevant information. Generally, information specificity is in two forms, knowledge and time specificity. Knowledge specificity refers to either scientific or technical knowledge or "knowledge of context, or knowledge of particular circumstances of time and place" (Choudhury and Sampler 1997:30). If acquiring the information presupposes special training and insights, the information is high in knowledge specificity in acquisition. The same holds for specificity in use, which often follows specificity in acquisition (Huber 1982). Knowledge specificity may reside in different people or units in an organization, called intra organizational knowledge specificity. Inter organizational knowledge specificity applies "if the knowledge required to interpret the information is restricted to members of a single organization."(op.cit.32) In this paper the inter organizational knowledge specificity in a network economy refers to the existence of knowledge that is specific to each single organization in the network reflecting that division of labor follows from a high degree of specialization.

Time specificity can be found in the dictum that the right information at the right place in the right time prevails over all other information. Time specificity in use reflects a fast loss of value if the information is not used immediately, whereas the time specificity in acquisition refers to an event like nature of information, an example is that the registration of the size of an earthquake must take place at the time of the quake. This example also conveys that specificity in use may not follow from specificity in acquisition.

\begin{tabular}{|l|l|l|}
\cline { 2 - 3 } \multicolumn{1}{c|}{} & \multicolumn{1}{c|}{ Time specificity } & \multicolumn{1}{c|}{$\begin{array}{c}\text { Knowledge } \\
\text { specificity }\end{array}$} \\
\hline $\begin{array}{l}\text { Specificity } \\
\text { in } \\
\text { acquisition }\end{array}$ & $\begin{array}{l}\text { Information that must } \\
\text { be acquired } \\
\text { immediately, or very } \\
\text { shortly, after it first } \\
\text { originates or becomes } \\
\text { available }\end{array}$ & $\begin{array}{l}\text { Information that } \\
\text { can be acquired } \\
\text { only by someone } \\
\text { with the required } \\
\text { specific knowledge }\end{array}$ \\
\hline $\begin{array}{l}\text { Specificity } \\
\text { in use }\end{array}$ & $\begin{array}{l}\text { Information that } \\
\text { decreases in value } \\
\text { unless used } \\
\text { immediately, or very } \\
\text { shortly, after it becomes } \\
\text { available }\end{array}$ & $\begin{array}{l}\text { Information that } \\
\text { can be effectively } \\
\text { used only by } \\
\text { someone with the } \\
\text { required specific } \\
\text { knowledge }\end{array}$ \\
\hline
\end{tabular}

Table 1: The specificity of information.

Source: Choudhury and Sampler 1997:29.

The information time specificity argument can be extended to business in general due to the proliferation of time-based competition (Stalk and Hout 1990, Wang and Barron 1997). Competition leaves few without a sting from time pressures that are translated into information requirements equally time sensitive. In this sense much information acquires time specificity that if put aside devalues or makes the information irrelevant.

Timeliness no longer only resides with products like newspapers, flight tickets, tomatoes or sophisticated electronic products. Since timeliness is associated with business in general the time specificity of information assets achieves a much wider relevance than that of a particular product or service characteristic. Further, shorter product lifecycles due to innovation speed up and due to customizations result in frequent change in product varieties which makes necessary a careful productcustomer tracking system demanding a management response alike the timeliness claim.

Knowledge specificity traditionally plays a significant role in strategic technology collaboration for product development (Badaracco 1991). As more technologies become systemic the knowledge interdependencies increase in use while relying upon knowledge specificity in acquisition (Teece 1987, Chesbrough and Teece 1996). In networks the knowledge specificity is a defining characteristic whether explained by the transaction cost economics of relational contracting due to asset specificity or explained by beneficial (knowledge) cooperation (Johanson and Mattson 1987). Knowledge specificity carries over into knowledge management issues of identification, storage and use.

\subsection{The Actor Network Distributed Knowledge Management Model}

The concept 'distributed' refers to an organization in which activities are located to those locations or entities where it is best performed, determined for example by skills, costs or resources (Galbraith and Lawler 1993). In our context, distributed normally also refers to independent organizations (companies) performing each their value-added activities.

In an actor network distributed model of knowledge management the acquisition of knowledge will not reside only within a single organization. The inter- 
organizational knowledge specificity reflects the differences in specialization and position in the network, for instance a supply chain. In any organization external business partners are a source of important business information. Therefore it remains a target in the establishment of a repository to convert various partnercompetitor systems into partnership systems sharing relevant and timely information about the significant environment of the company. Facing increasing competition in e.g. customer response time organizations are looking for tools to up-date the repository at a continuous basis, when thresholds are reached that elicits signals calling for attention. The more frequent that threshold information enters into daily routines the more decision support is derived. The knowledge specificity of a partner may be merged with that of another that converts the information into new specific knowledge. This knowledge fed back to the contributing partners' local applications generates opportunity of specific knowledge.

If we merge these aspects of information processing in an inclusive environment we end up with a system holding distributed knowledge repositories at the same time as showing decision support qualities due to information timeliness and relevancy to the network actors. The network makes partners' time specific knowledge available for processing along with the actor's own specific knowledge.

An example of the distributed knowledge management approach is the EUREKA case. Peer production proprietary, not commons-based - as first used to solve the imperfection of hierarchical organization in Xerox's Eureka system organizing questions from and answers to field technicians about failures of photocopiers (Bobrow, et al). In reaction to performance failure the firm created a decentralized communications system for technicians to post questions, a peer-reviewed system for technicians to answer questions, and a database library of past questions and answers available to technicians who confront new problems.

"Eureka flipped the traditional hierarchical conception of knowledge in a machine as codified by engineers and implemented by instruction following technicians. The knowledge content of the machine was now understood to be something that is incomplete when it leaves the design board, and is completed over the life of the machines by technicians who share questions and solutions on a peerreview, volunteer model." (Benkler 2002-3, p.43).

Beneath, find the decision process of each actor in the network and the distributed, specific knowledge. The figure represents a succession of nested knowledge creations in a distributed environment (Riempp and Nastansky 1997). Each actor conducts independent, separate information management allowing for message objects for the exchange of specific knowledge items in the network.

Figure 1 illustrates two triangles, each presenting an exchange relation of Knowledge, Information, and Data (KID) where data is a low level descriptor, information an application descriptor, and knowledge an actor network descriptor. For each actor, a number of internal activities are shown. The activities engaged in a KID relation are highlighted in order to emphasize the external relation.

Activities engaged in more than one KID exchange relation are multi-purpose activities. The activities may represent a unit of a business process. A unit may have different levels of abstraction depending on the purpose being served, the viewpoint and the context of the external relation, e.g. a sub business process, a general task, or a detailed sub-task.

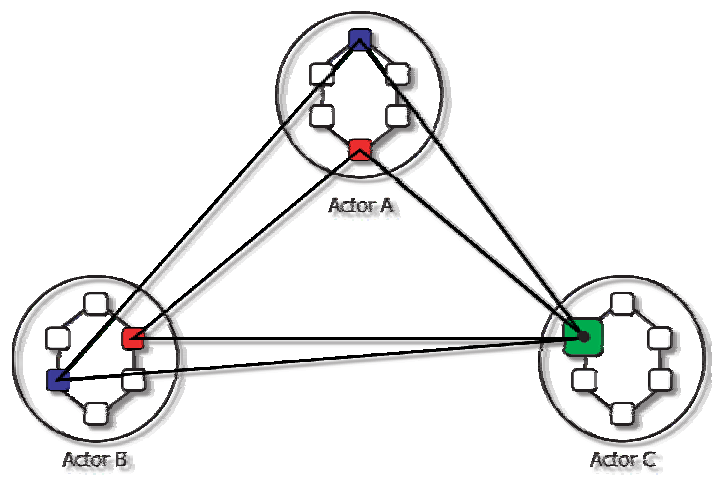

Figure 1: Information specificity of actor network distributed knowledge management - multi-purpose activities.

Note: The quadrants represent activities where the small quadrants represent single purpose activities and the larger quadrant represents a multi purpose activity. A circle represents an organization or an individual. The chain of activities within a circle represents a simplified business process in an organization, and the lines connecting the activities are knowledge, information and data (KID) exchange relations. The legs of the triangles are KID exchange relations between logically related activities, whereas the triangle itself represents a distributed knowledge network.

In figure 2 below the proposed model of a supply network decision support system based upon well-defined knowledge repositories is found. 
Beneath in table 2, we have outlined a simplified business structure in which the company exchanges information with a representative dealer and an end-user (customer) of its product or service. To analyze the nature of the relationships we present the relationship in more detail. This is obtained if we consider a manufacturing company and the dealer as a service company whereas the end-user may be in any kind of trade. The determination of actors is meant as illustration of the model that is considered to be generally relevant in networks. For details see Larsen et al. (1999), Larsen \& Pedersen (2001), Pedersen \& Larsen (2001), and Larsen \& Pedersen (2003).

In the matrix below only knowledge regarding product maintenance and replacement is entered whereas business information such as prices, quotes, orders, and payments, all have been disregarded since that are standard contract information exchange in all businesses. In this example the business information interchange does not call upon a decision support model though in fact such a model alongside the one beneath may be relevant, too.

\begin{tabular}{|l|l|l|l|}
\hline $\begin{array}{l}\text { To: } \\
\text { From: }\end{array}$ & Producer & \multicolumn{1}{|c|}{ Dealer } & End user \\
\hline Producer & $\begin{array}{l}\text { Internal } \\
\text { knowledge } \\
\text { handling }\end{array}$ & $\begin{array}{l}\text { Product } \\
\text { services } \\
\text { knowledge } \\
\text { Stock mix } \\
\text { according to } \\
\text { PSM }\end{array}$ & $\begin{array}{l}\text { Self service } \\
\text { manuals } \\
\text { On line } \\
\text { advice } \\
\text { End-user } \\
\text { community }\end{array}$ \\
\hline Dealer & $\begin{array}{l}\text { State of } \\
\text { stock mix } \\
\text { Crisis } \\
\text { management } \\
\text { spare parts } \\
\text { stock }\end{array}$ & $\begin{array}{l}\text { Internal } \\
\text { knowledge } \\
\text { handling }\end{array}$ & $\begin{array}{l}\text { Allocated } \\
\text { (reserved) } \\
\text { spare parts in } \\
\text { stock } \\
\text { End user }\end{array}$ \\
$\begin{array}{l}\text { Hours of } \\
\text { product use } \\
\text { FAQs } \\
\text { revealing } \\
\text { usage } \\
\text { problems } \\
\text { Time } \\
\text { critical } \\
\text { services }\end{array}$ & $\begin{array}{l}\text { Maintenance } \\
\text { support } \\
\text { Rervices } \\
\text { support }\end{array}$ & $\begin{array}{l}\text { Product } \\
\text { support }\end{array}$ & $\begin{array}{l}\text { Internal } \\
\text { knowledge } \\
\text { handling }\end{array}$ \\
\hline
\end{tabular}

Table 2: A distributed knowledge management model.

The knowledge management approach stresses source of knowledge and needs for sharing. In this model, sharing is given by the nature of the relationships between the three actors of a supply network. They are truly interdependent if all parties hold specific information. That is the case if the dealer's database on customers also make them know the propensities for their customers to repair rather than replace parts and components, the propensity to cater for risk amongst their customers, all adding up to a knowledge of the immediate expected demand for services and spare parts. At the same time the dealers exploit this knowledge not in terms of a large amount of data but in terms of consolidated data, i.e. the demand for allocated (reserved) stock and for a crisis managing stock to cope with unexpected demand.

The producer on the other hand receives information from end-users' hours of use and their need for use of repair manuals and instructions, the community facility giving access to attitudes as well as actual problems of operating the product of the producer. The producer learns from his end-users what becomes valuable knowledge when redesigning the product, and changing components or materials used in the product.

Further, the end-user is in the position to offer information not only to the producer but also in terms of actual behavior concerning their needs for replacements, repair-sets, and other relevant products and services to their dealer. Hence, on a continuous basis the dealer receives information about end-users needs and propensities to buy or repair converting this knowledge into privileged information according to a local model.

Dealers receive general information on product life and services requirements according to continuously generated data models from the producer. This information is merged with the dealer's knowledge of his customer base. The merged knowledge comes out as privileged dealer knowledge useful for the planning of his stock and supplementary services to meet the immediate needs of his market.

The three actors of the supply network all hold privileged knowledge that, offered as continuous data to the other actors, make the aggregate information emerge as new specific knowledge while being proper as decision support for each actor in his particular circumstances. The faster the information exchange cycle, the more the quality of relevance is supplemented with the one of timeliness adding up to a new category, i.e. the distributed knowledge decision support. 


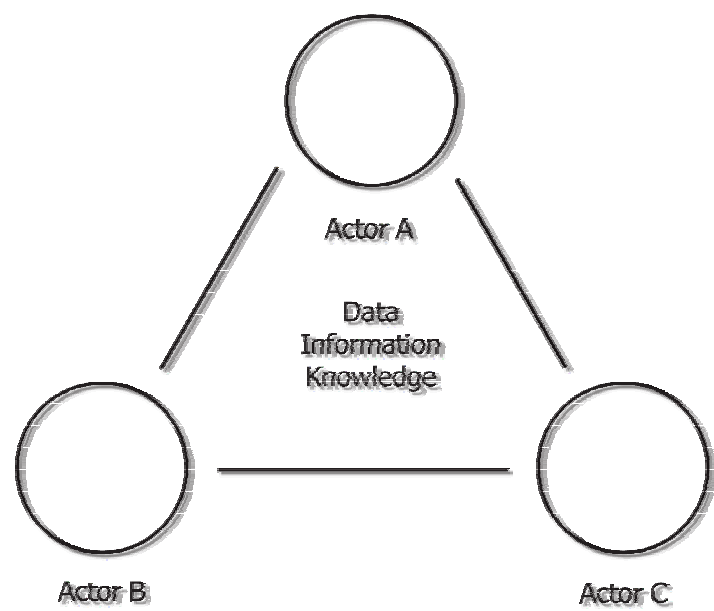

Figure 2. The actor network distributed knowledge management model.

Only by abandoning the dualistic model where the firm confronts an anonymous market does the nature of business-to-business and business-to-consumer relations emerge as complex interdependent relationships, i.e. the ground for evolving strategic knowledge management options. The firm has to be perceived in a heterogeneous, structured rather than a homogenous, environment where identified competitors and customers represent opportunities but also challenges to the firm (Anderson et al. 1997). The co-existence of customer relations, business partners and relationships, and networks for distributed knowledge management coalesce into what Venkatraman and Henderson (1998) have named the "architecture for virtual organizing" stressing that these are strategic characteristics applicable to every organization.

The table below presents a number of general examples from various industries of actors of distributed knowledge management networks and their primary knowledge exchange, i.e. the 'intermediaries' that trigger the actor network.

\begin{tabular}{|l|l|l|l|l|}
\hline Industry & Actor A & Actor B & Actor C & $\begin{array}{l}\text { Network } \\
\text { Inter- } \\
\text { mediary }\end{array}$ \\
\hline $\begin{array}{l}\text { Manu- } \\
\text { facturing }\end{array}$ & $\begin{array}{l}\text { Producer } \\
\text { of } \\
\text { fertilizer } \\
\text { sprayers }\end{array}$ & $\begin{array}{l}\text { Dealers of } \\
\text { sprayers } \\
\text { and spare } \\
\text { parts }\end{array}$ & Farmers & $\begin{array}{l}\text { Product } \\
\text { consump-tion } \\
\text { data }\end{array}$ \\
\hline $\begin{array}{l}\text { Profes- } \\
\text { sional } \\
\text { Service }\end{array}$ & $\begin{array}{l}\text { Profes- } \\
\text { sional } \\
\text { service } \\
\text { provider }\end{array}$ & $\begin{array}{l}\text { Interme- } \\
\text { diary }\end{array}$ & Client & $\begin{array}{l}\text { Project } \\
\text { specific } \\
\text { knowledge }\end{array}$ \\
\hline
\end{tabular}

\begin{tabular}{|l|l|l|l|l|}
\hline & $\begin{array}{l}\text { (Financin } \\
\text { g partner) }\end{array}$ & Dectors & Patients & $\begin{array}{l}\text { Patient } \\
\text { medical } \\
\text { history and } \\
\text { treatment } \\
\text { record }\end{array}$ \\
\hline $\begin{array}{l}\text { Health } \\
\text { Care }\end{array}$ & $\begin{array}{l}\text { Medical } \\
\text { Organice } \\
\text { tion }\end{array}$ & Dona- \\
\hline $\begin{array}{l}\text { Tele } \\
\text { commu- } \\
\text { nication }\end{array}$ & $\begin{array}{l}\text { National } \\
\text { Organiza- } \\
\text { tion }\end{array}$ & Supplier & $\begin{array}{l}\text { Customer } \\
\text { (e.g. Public } \\
\text { Telecom- } \\
\text { munica- } \\
\text { tions } \\
\text { Operator) }\end{array}$ & $\begin{array}{l}\text { Information } \\
\text { and commu- } \\
\text { nication } \\
\text { system } \\
\text { specifica- } \\
\text { tions }\end{array}$ \\
\hline Table & $3:$ Examples of & distributed & knowledge \\
\hline
\end{tabular}
management actor networks.

The 'intermediary' triggers each actor's information specific contribution and makes up for the nature of economizing in the actor network. The efficiency improvement for actor A would normally differ from the kind of efficiency improvement achieved by B, and so forth. In the manufacturing case actor $\mathrm{A}$ achieves product state information economizing on product improvements and maintenance, whereas actor B limits capital expenditures on stock, and actor $\mathrm{C}$ decreases maintenance time and its costs. Equally different competitive advantages coexist in the other actor networks.

Compared to a linear model of business processes (e.g. Porter 1985) the overall efficiency of the actor network distributed knowledge model is superior because it provides an information feedback mechanism to the value chain enhancing the information base of each production function. In a competitive marketplace knowledge exchange only takes place if markets exist for each exchange, and markets exists only if property rights are defined (Arrow 1974, Coase 1992). Markets are hard to bring about for specific knowledge as information good with uncertain value to the procurer, a very limited market potential and with relevance for a very limited period of time, unless provided as a service and then for a period of time in case of which procurer uncertainty increases. Thus, markets in most cases will not come into existence for specific knowledge exchange in networks.

Peer knowledge cannot be appropriated completely when associated with a common knowledge domain, as is the case of professions. Yet, in all professions the ability to synthesize peer knowledge with local, specific knowledge distinguishes the excellent from the mediocre practitioner (Schon 1983).

The actor network model of distributed knowledge is based upon peer knowledge coming into existence on the explicit premise that no property rights can be established 
due to prohibitive transaction costs and to a break down of incentives if any actor appropriate benefits on behalf of others (Benkler 2002-3).

The actors are renumerated by each their own product though each of these, in each their way, has benefited from peer knowledge interchange.

\section{Model Robustness}

This section provides a discussion of the robustness of the DKM Model. Robustness refers to how changes in the actor network influence the properties of the model.

A decision support system generates decisions or decision suggestions for the user. The double conversion loop DKM model converts distributed knowledge into multi-decision making suggestions or choices for the different actors in the network creating a symmetric incentive structure. An actor network peer production of knowledge that are beneficial for each actor creates an equilibrium of incentives. If the equilibrium is up-set due to diminishing differentiation in peer produced knowledge over a period, then incentives for maintaining the knowledge production erodes. If a single actor (minor) out of a large number of actors looses interest in the peer production the equilibrium last, but if major actors (and numbers) defect from peer production then peer knowledge is bound to appear less trustworthy and the equilibrium will break-down.

These features make the double conversion actor network knowledge model more robust than a single conversion model that only relies upon a separation between acquiring and using information in a decision context disregarding peer knowledge production.

Which conditions are required to create and maintain peer production?

The analysis of peer production of knowledge assumes lower information opportunity costs than markets and hierarchies for knowledge exchange. If peer production breaks down then there is higher costs involved if rebuilding takes place using either prices or contracts as basis for exchange. Therefore actors have incentives to maintain the peer production as far as possible. The competitive balance between the organizations depends upon each actor's capability and capacity to transform peer produced into specific knowledge.

"The hypothesis is that rich information exchange among large sets of agents free to communicate and use existing information resources cheaply will create sufficiently substantial information gains of this sort ... to overcome the added information exchange costs necessary to overcome the absence of pricing and managerial direction, and the added coordination costs created by the lack of property and contract as institutional bases for structuring coordination (Benkler, 2002-3, p. 43).

Peer production of knowledge does not exclude contractual exchange of codified knowledge (as in patents, copyright,) but complement these formal types of knowledge. Formal knowledge is protected (more or less effectively) against undue appropriation. Peer produced knowledge would be curtailed if it was appropriated as a private good. In our model peer produced knowledge is merged with specific knowledge before acquiring economic value for the appropriator.

A distributed knowledge actor network argues that development of local knowledge specificity requires access to peer produced knowledge. If the latter is lacking risk of innovation failure increases. We base this proposition on empirical findings showing no core competence structure amongst large companies measured by the rod of required product portfolio competences. Instead we find "distributed competences" relating technological competence to a wider environment. Peer produced knowledge feeds the distributed competence structure and not product specific knowledge (Grandstrand et al 1997). Innovation flows from distributed competence management appeared stronger than from product focused competence structures.

Knowledge is perceived as a tool instead of the classic "message-object" model from Shannon-Weaver in studies of distributed teams using metaphors of knowledge, differentiating embedded from mobile knowledge like in our distinction between specific knowledge (embedded) and peer produced knowledge (mobile) (Kanfer et al 2000).

How do we achieve distributed knowledge management in organizations focused on product specific (embedded) knowledge? Given a distributed knowledge actor network has come about, what are the chances that it will last?

In the following sections the static and dynamic aspects of the actor network model of distributed knowledge is analyzed.

\subsection{Static aspects of the DKM Model}

In the following paragraphs we list propositions on the robustness of the actor network distributed knowledge model. Each proposition should be considered a research issue to address in the future.

(Proposition 1) Information capability of the network actors matches each other if peer knowledge required of 
one would meet the requirements of another. The specificity rests upon the business of the actors's position in the network and not upon the peer knowledge. A network may rest its business case upon time specificity in repair and maintenance due to narrow time windows of operations as in the airlines flight RMS (replacementmaintenance-service) industry. Only actors acting on knowledge timeliness would fit in this network. How do network actors establish that partners have requisite information capability?

(Proposition 2) Allocation flexibility. A distributed knowledge network with transactions that trigger decisions designed to maximize the total revenue of the network is viable if revenue is distributed proportional to the investment asset specificity of the actors (Teece 1987). Network economies are achieved on the condition of complementary actor incentives. Systems inherent mismatch would allow for variations in knowledge or time specificity that generally is of complementary nature but would disrupt the network if of competing nature. How do network actors obtain requisite complementarity in peer knowledge?

(Proposition 3) Incentives for knowledge creation reside in each actor. The network actors do not have to allocate a knowledge repository in a single network node thus the distributed knowledge model design is nonhierarchical and non-centralized. The distributed knowledge model leaves scope for the design of single as well multi-node repositories according to network characteristics and peer knowledge. An unequal development in knowledge creation jeopardizes incentive compatibility across the actor network. When will knowledge network effects align and when misalign actor incentives?

(Proposition 4) Trust in network actors looms high on the agenda in distributed knowledge management for the reason of non-recoverable specific assets invested in the network cooperation. The level of investment specificity determines the degree of lock-in. Networks with highly co-specialized assets reflect a higher level of trust than networks struggling to balance the risks and the benefits amongst the participants (Teece 1987). Generally, trust is stronger if strings and formalities upon network participants' peer production of knowledge are informal. Maintaining peer production without evaluation of its relevance to knowledge specificity allows for detraction of knowledge creation. How does the organization create yardsticks for peer knowledge engagement?

(Proposition 5) Trust in the network systems represents trust in a network as a collective endeavor or a community where laggards and other deviations trigger control behavior (Bobrow et al. 2003). Monitoring the network actors may jeopardize the objective, viz. to install trust in the common system. Which yardsticks for knowledge assessment are compatible with trust building in actor networks?

(Proposition 6) Incentive compatibility or congruency determines the viability of a distributed knowledge actor network. If incentive compatibility prevails, the network achieves robustness against external shocks, and the participants themselves raise voice if peers decline to participate or if low quality knowledge is offered. If a network is challenged by another - competing - actornetwork, a new knowledge dynamic results (see below). Will competing actor-networks create network closure or stimulate peer knowledge production acting as an incentive?

(Proposition 7) Stability of knowledge specificity. Asymmetric knowledge lifecycles due to different information value depreciation schemes for specific knowledge would jeopardize the incentives for peer knowledge creation. Knowledge specificity creation should be based on investments balanced by benefits. Depreciation schemes should probably not be equal across different domains of knowledge. How will domain differences in knowledge specificity be properly acknowledged in an organization? If only seen in regard to product performance (financial), peer knowledge production risk becomes undervalued to the detriment of knowledge specificity. How is the interdependency between peer knowledge and specificity established in an actor-network?

(Proposition 8) The higher the information capability of an actor, the more marginal is the investment in distributed knowledge management if knowledge specificity rests upon standards. Yet, knowledge specificity may be a competitive advantage factor. If the knowledge specificity diminishes then so does the competitive advantage. The disadvantage from loss of specificity in knowledge may be balanced by time specificity or another asset specificity derived from the knowledge exchange in the network. That would be the case if one asset attribute, e.g. the time sensitivity, remains intact after loss of knowledge specificity in other regards though leaving a lower entry barrier for competitors to the network. Can knowledge specificity adapt to new environmental conditions changing one or more attributes?

(Proposition 9) Lock-in has to be considered in all actor networks where the actors have invested to create transaction specific advantages from knowledge specificity. Contracts are rarely considered an assurance 
against losses in actor networks due to the dynamics of the peer production relationships. A network with cospecialized assets raises interdependence at the cost of the freedom to opt out. The interdependency between peer knowledge and specificity determines the degree of lockin, the stronger the peer production the less likely is a lock-in and the stronger the knowledge specificity the more likely it is conditioned by asset specificity.

\subsection{Dynamic aspects of the DKM Model}

(Proposition 2-1) Knowledge stability over its lifecycle is a point reflecting unequal diminishing value. Network actors may experience that knowledge asset specificity deteriorate before that of other networks. For these actors the value of the network diminishes but long-term benefits have to be evaluated before decision making about exit from peer production of knowledge. (See also prop. 7.)

(Proposition 2-2) Incentive instability reflects that knowledge creation in actor networks is faster than if conducted in isolation but at the risk of incentive changes that polarize the participants. The sensitivity in knowledge specificity may be countered by the peer knowledge perceived value for the actor network making the network resistant to changes due to changes in knowledge specificity. For instance in a supply chain network, robustness derives from combinations of knowledge and time specificity that may uphold unevenly as structure in the final demand changes. Yet, a period of adaptation to the new market conditions may be acceptable to the actors.

(Proposition 2-3) Information system selfcontrol/autonomy will contribute to a steady state model where knowledge accuracy and validity enhance decisionmaking powers of the actors. The advantages anyone derives at any time from the distributed knowledge system come from previous quality of knowledge inputs. If these inputs deteriorate so will the decisions that rely upon that knowledge.

(Proposition 2-4) Horizontal market dynamic. Horizontal competing distributed knowledge systems invite opportunism of network actors. If competing networks appear, the peer knowledge production risks being corrupted so the decision-making strength of the actors in the network deteriorates.

(Proposition 2-5) Vertical market dynamics. If valueadding competitors exploit information as proxies for supplementary services and complementary products not offered in the original network that invites the participants to dump previous investments. The potential exit of actors or the opportunistic behavior of those left threatens the viability of the network. In the long term the network may not be competitive but will be abandoned.

The dynamic aspects of distributed knowledge models reflect contingencies of actor-networks much more than do knowledge network's interdependency models (Alstyne 1997).

These propositions on the DKM model are not preemptive but capture some of the challenging issues that these actor-networks face and thus what research should be about in this field. Though informed by behavioral theory knowledge specificity requires more analytic tools including information models to capture its complex dynamics.

\section{Conclusion and Perspectives}

The distributed knowledge model relies upon knowledge specific decision support with symmetric incentives for peer production of knowledge. The model merges specific knowledge with peer knowledge from an actor-network for decision support specific for each actor in recognition of actor role differences. Understanding how the viability of knowledge management depends upon symmetric incentives - peer knowledge production - and, in various ways, on appropriation of advantages from knowledge specificity has been the objective of this research. From observations of actor networks we know that stability may not easily be attained nor may it continue. In our analysis we have offered suggestions for research into the static as well as the dynamic aspects of distributed knowledge in actor-networks. In answering the research question of what the necessary conditions are for establishing and maintaining robustness of a distributed knowledge management model, 9 static and 5 dynamic aspects of robustness have been suggested.

Like other network applications, the design of actor network distributed knowledge management system represents a real challenge to business. With outsourcing and technological complementarities in abundance the opportunities to take advantage of this model are prolific but challenging opportunities.

\section{REFERENCES}

[1] Nonaka, I. \& Byosiere, P. \& Borucki, C.C. \& Konno, N., 1994. Organisational Knowledge Creation Theory: A First Comprehensive Test. International Business Review. Special Issue on Knowledge in Organisations, Knowledge Transfer, and Cooperative Strategies. 3/4, 337-351. 
[2] Nonaka, I. and Konno, N., 1998. The Concept of "Ba": Building a Foundation for Knowledge Creation. California Management Review, 40(3), 40-54.

[3] Nonaka, I. and Takeuchi, H., 1995. The Knowledge Creating Company - How Japanese Companies Create the Dynamics of Innovation. Oxford University Press.

[4] Nonaka, I., 1994. A Dynamic Theory of Organisational Knowledge Creation. Organisation Science, 5, 14-37.

[5] El Sawy, O.A. and Bowles, G., 1997. Redesigning the Customer Support Process for the Electronic Economy: Insights from Storage Dimensions. MIS Quarterly, December, 457-483.

[6] Favela, J. 1997. Capture and Dissemination of Specialized Knowledge in Network Organisations. Journal of Organisational Computing and Electronic Commerce 7 (2\&3) 201-226.

[7] Davenport, T.H. and Klahr, P., 1998. Managing Customer Support Knowledge, California Management Review 40(3) 195-208.

[8] Choudhury, V. and Sampler, J. L., 1997. Information Specificity and Environmental Scanning: An Economic Perspective. MIS Quarterly, March 21(1) 25-53.

[9] Benkler, Yochai, 2002-3, Coase's Penguin, or, Linux and The Nature of the Firm. Forthcoming in 112 Yale L. J. (Winter 2002-03).

[10] Coase, R.H. 1937, The Nature of the Firm. Economica, vol.4, November, 386-405.

[11] Williamson, O. E., 1985. The Economic Institutions of Capitalism. New York: The Free Press.

[12] Adler, Paul S., 2001, Market, Hierarchy, and Trust: The Knowledge Economy and the Future of Capitalism, Organization Science, 214-234 (March-April 2001).

[13] Ciborra, Claudio and Andreu, Rafael, 1998. Organisational Learning and Core Capabilities Development: The Role of IT. in Information Technology and Organisational Transformation. Edited by R. Galliers and W.R.J. Baets. John Wiley and Sons Ltd.

[14] Borghoff, U.M., 1997. Information Technology for Knowledge Management. Journal of Universal Computer Science. 3(8), 835-842.

[15] Davenport, T. and Prusak, L., 1998. Working Knowledge - How Organisations Manage What They Know. Harvard Business School Press, Boston, MA.

[16] Hagel, J. and Rayport, J., 1997. The Coming Battle for Customer Information. Harvard Business Review, January-February, 53-65.

[17] Strader, T. J.; Fu-Ren Lin; Shaw, M.J. 1998. Information Infrastructure for electronic virtual organisation management. Decision Support Systems 23, 75-94.

[18] Sridhar, S. 1998. Decision Support using the Intranet. Decision Support Systems, 23, 19-28.

[19] Callon, M., 1991. Techno-economic networks and irreversibility. In J. Law,ed. A Sociology of Monsters. Essays on Power, Technology and Domination. Sociological Review Monograph 38. London: Routledge.

[20] Hull, R.,V. Walsh, Green, K., \& McMeekin, A. 1999. The Techno-Economic: Perspectives for Analysis and
Intervention. Journal of Technology Transfer, 24. 185195.

[21] Porter, M. E., 1990. The Competitive Advantage of Nations. Macmillan, N.Y.

[22] Porter, M.E. 1998a. Clusters and the New Economics of Competition. Harvard Business Review. NovemberDecember 76(6) 77-90.

[23] Porter, M.E. 1998b. The Adam Smith Adress: Location, Clusters, and the "New" Microeconomics of Competition. Business Economics. Washington, January 33(1) 7-13.

[24] Wernerfelt, B. 1984. A Resource-based view of the firm. Strategic Management Journal 5, 171-180.

[25] Milgrom, P. and J. Roberts, 1992. Economics, Organisation and Management. Englewood Cliffs, N.J. Prentice-Hall International, Inc.

[26] Foss, N. J. (ed.), 1997. The Resource-based Perspective on the Firm. London: Routledge Kegan Paul.

[27] Williamson, O. E., 1986. Economic Organization. Brighton: Wheatsheaf Books Ltd.

[28] Williamson, O. E., 1994. Transaction cost economics and organization theory. In Smelser, N.J. and Swedberg,R. (eds) The Handbook of Economic Sociology. Princeton U P. 77-107.

[29] Huber, G., 1982. Organisational Information Systems: Determinants of Their Performance and Behavior. Management Science 28 (2) February. 138-155.

[30] Stalk, G. and Hout, T.M. (1990). Competing Against Time. N.Y. The Free Press.

[31] Wang, E. T.G. and Barron, T. 1997. Computing services supply management: Incentives, information, and communication. Decision Support Systems 19, 123-148.

[32] Badaracco, Jr. Joseph L., 1991. The Knowledge Link. Harvard Business School Press. Boston, Mass.

[33] Teece, D. J. (1987). Profiting from technological innovations: Implications for integration, collaboration, licensing and public policy. In Teece, D. J. Ed. (1987). The Competitive Challenge. Cambridge. Mass.

[34] Chesbrough, H.W. and Teece, D. J. 1996. When is Virtual Virtuous? Organizing for Innovation. Harvard Business Review, 74, Jan-Feb. 65-73.

[35] Johanson, J. and Mattsson, L.-G. 1987. Interorganizational relations in industrial systems: a network approach compared with the transaction-cost approach. International Studies of Management and Organisation. 17. 34-48.

[36] Galbraith, J.R. and Lawler III, E.E., 1993. Organising for the Future. The New Logic for Managing Complex Organisations. San Francisco: Jossey-Bass Publishers.

[37] Bobrow, Daniel G., Robert Cheslow, and Jack Whalen (2003). Community Knowledge Sharing in Practice, Seen July 2003. http://jonescenter.wharton.upenn.edu/Virtual Communities/whalen.pdf.

[38] Riempp, G. and Nastansky, L., 1997. From Islands to Flexible Business Process Networks- Enabling the Interaction of Distributed Workflow Management Systems. Proceedings of the 5th European Conference on Information Systems.Vol. 1, 481-496. 
[39] Larsen, M.H. \& Pedersen, M.K. (2001). Distributed Knowledge Management in Health Care Administration. Chapter XII in Spil, T.A.M. \& Stegwee, R.A. (editors) (2001). Strategies for Healthcare Information Systems Transformation of the Healthcare Chain in to the Future. IDEA Publishing, pp. 182-197.

[40] Larsen, M.H. \& Pedersen, M.K. (2003). Strategizing for Distributed Knowledge Management. In Andersen, K.V., Elliot, S., Swatman, P.M.C., Trauth, E.M. \& BjørnAndersen, N. (2003). Seeking Success in e-Business: A Multidisciplinary Approach. IFIP International Federation for Information Processing. Kluwer Academic Publishers. Volume 252, pp. 539-556.

[41] Larsen, M.H.; L.R. Franck, and Pedersen, M. Kühn. 1999. Frontline CALS - Extranet Enabled Support of Customer Relations Based on Product State Information. Proceedings of the 7th European Conference on Information Systems. Copenhagen, June, 302-319.

[42] Pedersen, M. Kühn \& Larsen, M.H. (2001). Distributed Knowledge Management based on Product State Models The Case of Decision Support in Health Care Administration. Decision Support Systems. Special issue on Knowledge Management. 31(1), pp. 139-158.

[43] Anderson, E.; Day, G.; Rangan, V.K. 1997. Strategic Channel Design. Sloan Management Review, June. 59-69.

[44] Venkatraman, N. and Henderson, J.C. 1998. Real Strategies for Virtual Organizing. Sloan Management Review, 40 (1) Fall, 33-48.

[45] Porter, M.E. (1985). Competitive Advantage: Creating and Sustaining Superior Performance. Free Press, New York.

[46] Arrow, K. 1974, The Limits of Organization. W.W. Norton \& Comp. N.Y.

[47] Coase, R.H. 1992, The Institutional Structure of Production. American Economic Review, 82 (4), December, 713-719.

[48] Schön, D. 1983, The Reflective Practitioner: How Professionals Thinks in Action. Basic Books, N.Y.

[49] Grandstrand, O. Patel, P. and Pavitt, K. (1997). Multitechnology Corporations: Why They Have "Distributed" Rather Than "Distinctive" Core Competencies. California Management Review 39 (4) Summer 8-25.

[50] Kanfer, A.G., Haythornthwaite, C.,Bruce, B.B., Bowker, G.C., Burbules, N.C. Porac, J.F., Wade, J. (2000). Modeling Distributed Knowledge Processes in next Generation Multidisciplinary Alliances. Information Systems Frontiers 2:3/4, 317-331.Zuboff, S. 1988. In the Age of the Smart Machine. N.Y. Basic Books.

[51] Alstyne, M. van, 1997. The State of Network Organisation: A Survey in Three Frameworks. Journal of Organisational Computing and Electronic Commerce. $7(2 \& 3), 83-151$. 